\title{
WHEN SHOULD ONE LOOK FOR IVS1+1G>A SPLICE MUTATION IN PATIENTS WITH NONSYNDROMIC SENSORINEURAL HEARING LOSS?
}

\author{
Olga Shubina-Oleinik, Marina Siniauskaya, Elena Merkulava, Anastasia Levaya-Smaliak, \\ Oleg Davydenko, Nina Danilenko
}

Institute of Genetics and Cytology, National Academy of Sciences of Belarus, Minsk, Belarus

Corresponding author: Olga Shubina-Oleinik, Institute of Genetics and Cytology, National Academy of Sciences of Belarus, Minsk, Belarus, e-mail: oleinik.olga@yahoo.co.uk

\begin{abstract}
Background: The splice site nucleotide substitution IVS1+1G>A in the non-coding part of the GJB2 gene is one of the recessive pathogenic mutations causing nonsyndromic sensorineural hearing loss (NSHL). We present here the results of a study of IVS1+1G >A among Belarusian patients with NSHL as well as among Belarusian controls with normal hearing.

Material and methods: The PCR-RFLP method was used for genotyping. All tested patients were subdivided into three groups: those who carried only one mutant allele of GJB2 exon 2 (group A, 28 patients), those with no mutation of GJB2 exon 2 (group B, 150 patients), and patients with two mutations previously detected in the second exon of GJB2 or with one mutation and a large GJB6 deletion $\triangle \mathrm{D} 13 \mathrm{~S} 1830$ (group C, 223 patients). Also 300 Belarusian people with normal hearing were screened for IVS1+1G $>$ A.
\end{abstract}

Results: We detected 7 patients with IVS1+1G>A mutation in the A group, which explained hearing loss in $25 \%$ of this deafness cohort. None of the B or C group patients carried the IVS1+1G>A mutation. We also did not find any IVS1+1G>A mutation carriers among the 300 Belarusian control people with normal hearing.

Conclusions: IVS1+1G $>$ A is the third-most frequent mutation (after 35delG and 312del14) among Belarusian patients with NSHL; its rate is $1.8 \%$ for the patient cohort we studied and the population frequency is below $0.33 \%$. We propose to include the IVS1+1G $>$ A mutation into a laboratory screening protocol for those patients with NSHL that carry one mutant allele of GJB2 exon 2.

Keywords: GJB2 • IVS1+1G>A • nonsyndromic deafness

¿CUÁNDO SE DEBE REALIZAR LA PRUEBA DE LA PRESENCIA DE LA MUTACIÓN

IVS1+1G>A DEL GEN GJB2 EN LOS PACIENTES CON LA PÉRDIDA AUDITIVA AISLADA DE TIPO NEUROSENSORIAL?

\section{Resumen}

Objetivos: La mutación IVS1+1G>A que provoca el trastorno del proceso de la composición de los exones, localizada en la zona no codificante del gen GJB2, es una de las variantes recesivas, patógenas que provocan la aparición de la pérdida auditiva aislada de tipo neurosensorial (LHEN). En este estudio se presentan los resultados de los análisis moleculares para detectar la presencia de la mutación IVS1+1G>A en los pacientes bielorrusos con LHEN y en el grupo de control de la población.

Materiales y métodos: La detección de la mutación IVS1+1G>A se ha realizado con el método PCR-RFLP. Los pacientes han sido divididos en tres subgrupos: heterocigotos desde el punto de vista de las mutaciones localizadas en el exón 2 del gen GJB2 (grupo A, 28 pacientes), pacientes sin mutación en el exón 2 del gen GJB2 (grupo B, 150 pacientes), pacientes con dos mutaciones recesivas del gen $G J B 2$, o los heterocigotos de dos genes complementarias con la mutación en la zona codificante del gen GJB2 y con la deleción del gen GJB6 $\triangle \mathrm{D} 13 S 1830$ (grupo C, 223 pacientes). También se ha realizado la evaluación de la frecuencia de portadores en el grupo de control que contaba 300 personas de procedencia bielorrusa sin pérdidas auditivas.

Resultados: En el grupo A se han detectado 7 casos de la mutación IVS1+1G $>$ A, con lo que se ha explicado el motivo de la pérdida auditiva en el $25 \%$ de los pacientes del grupo analizado. En el grupo B y C no se ha detectado ningún caso de la mutación IVS1+1G>A. En el grupo de control de la población tampoco se ha constatado la aparición de la mutación IVS1+1G>A. 
Conclusiones: La mutación IVS1+1G>A del gen GJB2 es la tercera mutación más común (después de 35 deIG y 312 del14 respectivamente) mutación en los pacientes bielorrusos con LHEN; su incidencia en el grupo del estudio se ha definido en un $1,8 \%$. La frecuencia de ser portador de esta mutación es menor de $0,33 \%$. Se sugiere entonces realizar los análisis para comprobar la presencia de la mutación IVS1+1G>A en los pacientes con la pérdida auditiva, y en particular de los heterocigotos desde el enfoque de la presencia de otras mutaciones del gen GJB2.

Palabras clave: $G J B 2 \cdot I V S 1+1 G>A \cdot$ pérdida auditiva aislada

\title{
КОГДА СЛЕДУЕТ ВЫПОЛЯТЬ ТЕСТ НА НАЛИЧИЕ МУТАЦИИ IVS1+1G >A ГЕНА GЈВ2 У ПАЦИЕНТОВ С НЕСИНДРОМАЛЬНОЙ НЕЙРОСЕНСОРНОЙ ТУГОУХОСТЬЮ?
}

\section{Изложение}

Цель: Мутация IVS1+1G>A, нарушающая процесс сплайсинга локализованная в некодирующей области гена GJB2 - это один из рецессивных, патогенных вариантов, которые приводят к появлению несиндромальной нейросенсорной тугоухости (NSHL). В работе представлены результаты молекулярных анализов на наличие мутации IVS1+1G>A у белорусских пациентов с NSHL и в демографической контрольной группе.

\begin{abstract}
Материалы и методы: Детекция мутации IVS1+1G>A проведена методом PCR-RFLP. Пациенты были разделены на три подгруппы: гетерозиготы в отношении мутаций, локализованных во втором экзоне гена GJB2 (группа А, 28 пациентов), пациенты без мутаций во втором экзоне гена GJB2 (группа Б, 150 человек), пациенты с двумя рецессивными мутациями гена GJB2, или компаунд - гетерозиготы, сочетающие мутацию в кодирующей области гена GJB2 и делецию гена GJB6 $\triangle \mathrm{D} 13 \mathrm{~S} 1830$ (группа Ц, 223 пациента). Произведена также оценка частоты носительства в демографической контрольной группе, состоящей из 300 человек белорусского происхождения без тугоухости.
\end{abstract}

Результаты: В группе А обнаружено 7 носителей мутации IVS1+1G>A, что объясняет генетическую природу тугоухости у $25 \%$ пациентов из анализированной группы. В группе Б и Ц не найдено ни одного случая мутации IVS1+1G>A. В демографической контрольной группе также не обнаружено мутации IVS1+1G>A.

Итоги: Мутация IVS1+1G>A гена GJB2 - третья по частоте (после 35 delG и 312del14 соответственно) мутация у белорусских пациентов с NSHL, в исследованной группе она встречается у 1,8\%. Частота носительства этой мутации в популяции ниже $0,33 \%$. Следовательно, рекомендуется тестировать на наличие мутации IVS1+1G>A пациентов с тугоухостью, в особенности гетерозигот по другим мутациям гена GJB2.

Ключевые слова: GJB2 • IVS1+1G>A • изолированная тугоухость

\section{KIEDY NALEŻY WYKONAĆ TEST NA OBECNOŚĆ MUTACJI IVS1+1G>A GENU GJB2 U PACJENTÓW Z IZOLOWANYM NIEDOSŁUCHEM ZMYSŁOWO-NERWOWYM?}

\section{Streszczenie}

Cele: Mutacja IVS1+1G>A zaburzająca proces składania eksonów, zlokalizowana w niekodującym obszarze genu GJB2 jest jednym z recesywnych, patogennych wariantów powodujących wystąpienie izolowanego, zmysłowo-nerwowego niedosłuchu (NSHL). W pracy przedstawiono wyniki analiz molekularnych na obecność mutacji IVS1+1G $>$ A u białoruskich pacjentów z NSHL oraz w populacyjnej grupie kontrolnej.

Materiał i metody: Detekcję mutacji IVS1+1G>A wykonano metodą PCR-RFLP. Pacjenci zostali podzielenie na trzy podgrupy: heterozygoty pod względem mutacji zlokalizowanych w 2 eksonie genu GJB2 (grupa A, 28 pacjentów), pacjenci bez mutacji w 2 eksonie genu GJB2 (grupa B, 150 pacjentów), pacjenci z dwiema recesywnymi mutacjami genu GJB2, lub heterozygoty dwugenowe komplementujące $\mathrm{z}$ mutacją $\mathrm{w}$ regionie kodującym genu GJB2 i delecją genu GJB6 $\triangle \mathrm{D} 13 \mathrm{~S} 1830$ (grupa C, 223 pacjentów). Wykonano również ocenę częstości nosicielstwa w populacyjnej grupie kontrolnej liczącej 300 osób pochodzenia białoruskiego bez niedosłuchu.

Wyniki: W grupie A wykryto 7 przypadków mutacji IVS1+1G>A, wyjaśniając tym samym podłoże niedosłuchu u 25\% pacjentów $\mathrm{z}$ analizowanej grupy. W grupie B i C nie wykryto żadnego przypadku mutacji IVS1+1G $>\mathrm{A}$. W populacyjnej grupie kontrolnej również nie stwierdzono wystąpienia mutacji IVS1+1G $>\mathrm{A}$. 
Wnioski: Mutacja IVS1+1G>A genu GJB2 jest trzecią pod względem częstości występowania (po 35 delG i 312 del14 odpowiednio) mutacją u białoruskich pacjentów z NSHL, jej częstość w badanej grupie określono na 1,8\%. Częstość nosicielstwa tej mutacji wynosi poniżej $0,33 \%$. Sugeruje się zatem przeprowadzanie analiz na obecność mutacji IVS1+1G>A u pacjentów z niedosłuchem, a w szczególności heterozygot pod względem innych mutacji genu GJB2.

Słowa kluczowe: $G J B 2 \bullet I V S 1+1 G>A \bullet$ izolowany niedosłuch

\section{Background}

Hearing loss (HL) is one of the most common congenital disorders in industrialised countries: its frequency (1:1000 births) exceeds that of many monogenic diseases [1-3]. Genetically and clinically, hereditary hearing loss or deafness comprise a heterogeneous group of diseases with different types of inheritance. Congenital HL is divided into two groups: syndromic and nonsyndromic.

Nonsyndromic hearing loss (NSHL) accounts for $60-70 \%$ of all forms of hereditary deafness [4]. The major portion of NSHL is related to autosomal-recessive variants, which commonly are the most severe. Despite the large number of chromosomal loci (about 120) and 70 genes associated with this disorder [4], the vast majority of NSHL cases are determined by a single locus (DFNB1) on the $13^{\text {th }}$ chromosome (Figure 1). There are two genes in this locus: GJB2 and GJB6, both encoding connexin proteins $[5,6]$. GJB2 mutations are the most frequent cause of NSHL in the majority of the world population, in some countries accounting for up to $50 \%$ of NSHL cases; two large deletions including the GJB6 gene region also cause hearing loss, though they occur with far less frequency $[1,7]$.

The GJB2 gene encodes a protein of the intercellular gap junction, connexin $26(\mathrm{Cx} 26)$. This connexin is one of the membrane transport proteins forming connexon (which consists of six connexin subunits). Connexins are responsible for recycling $\mathrm{K}^{+}$as well as for the exchange of metabolites and signaling molecules in the organ of Corti, major requirements for mechano-electric transduction [8,9]. GJB2 is located in the DFNB1 locus on the long arm of the $13^{\text {th }}$ chromosome and consists of two exons, but only the second is protein-coding. Over 110 different mutations have been already detected in GJB2, 90 of which determine the development of nonsyndromic deafness [4]. Various ethnic groups are characterised by spectrum specificity and different frequencies of pathogenic mutations in GJB2, usually with a predominance of only one of the pathogenic variants [10].

In Europeans, the most frequent mutation causing NSHL is a deletion of one guanine within the six-guanine sequence at the beginning of the second GJB2 exon termed 35 delG [1]. This deletion is responsible for $70-90 \%$ of all pathogenic mutations in the GJB2 gene [4]. Despite the high frequency of 35delG and other mutations in the GJB2 gene, for a substantial proportion of patients with NSHL (10-15\%), only one pathogenic mutated recessive allele has been found in the course of direct sequencing of the GJB2 coding region [11-13], so the precise genetic basis of hearing loss for these patients remains elusive.

Along with the GJB2 coding region, the non-coding first exon and intron have been analysed in several studies to establish the second defect in the same gene, and some pathogenic mutations leading to NSHL have been identified [14-16]. When the splice site mutation in GJB2 IVS1+1G $>$ A (also called $-3170 \mathrm{G}>\mathrm{A}$ mutation) rs80338940, was originally reported, it was considered to be rare, with uncertain opinion about its pathogenicity $[14,15]$. The lack of transcription or instability of the transcript carrying IVS $1+1 \mathrm{G}>\mathrm{A}$ substitution in patients with IVS1 $+1 \mathrm{G}>\mathrm{A} / 35 \mathrm{delG}$ mutations suggested a pathological role of IVS1+1G>A mutation [17]. Screening of patients from different European countries (mainly in Eastern Europe) has revealed that the mutation IVS $1+1 \mathrm{G}>\mathrm{A}$ is common among patients with only one pathogenic mutated allele in the coding exon 2 of the GJB2 gene, including those who carry the mutation $35 \mathrm{delG}[3,13,18-22]$.

Recently, we have reported that $35 \mathrm{delG}$ is the main cause of hearing defects in 391 Belarusian patients with NSHL [23]. Genotyping of those patients showed that $46 \%$ were homozygous for the single nucleotide deletion 35delG, 13\% had only one mutant allele, whereas for $41 \%$ patients no $35 \mathrm{delG}$ mutation was identified [23]. To investigate the cause of hearing loss in the patients with the $35 \mathrm{delG}$ heterozygous genotype, as well as for those without this mutation, SSCP analysis followed by sequencing was carried out. As a result, six other mutation variants were found in the GJB2 second exon. The patient group was also checked for the presence of a large deletion that includes the GJB6 gene: $\triangle \mathrm{D} 13 \mathrm{~S} 1830$ ), and it was detected in three patients (Table 1). But still for 28 patients with only one mutant allele, and for 150 patients with no mutations in the GJB2 exon 2, the genetic basis of their NSHL, if any, remained uncertain.

Here, we present the results of the next step in our studies of the genetic basis for NSHL in Belarus: 1) we screened all of our patients (391) for IVS1+1G $>$ A splice mutation in the DFNB1 locus, and 2) we genotyped 300 native Belarusian

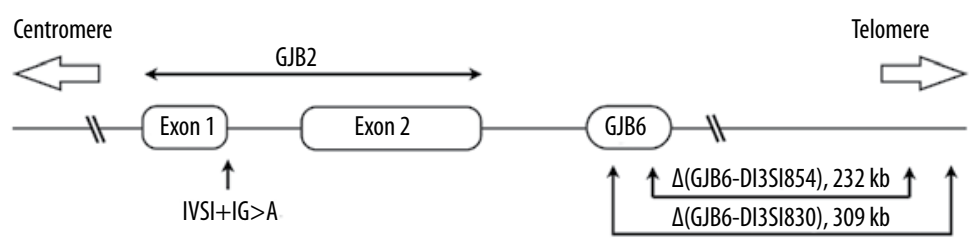

Figure 1. Location of the two genes GJB2 and GJB6 on chromosome 13q11-12 (from [11] with modifications) 
Table 1. Rates of IVS1+1G>A splice site mutation and other GJB2 and $\triangle \mathrm{D} 13 \mathrm{~S} 1830$ mutations in Belarus NSHL cohort of 391 patients*

\begin{tabular}{|c|c|c|}
\hline GJB2 genotype & $\begin{array}{r}\text { Numb } \\
\text { wit } \\
\text { (\% of }\end{array}$ & $\begin{array}{l}\text { r of patients } \\
\text { mutation } \\
\text { atient group) }\end{array}$ \\
\hline IVS1+1G>A / 35delG & 6 & (1.53\%) \\
\hline IVS1+1G>A / 312del 14 & 1 & $(0.26 \%)$ \\
\hline $35 \mathrm{delG} / 35 \mathrm{delG}$ & 178 & $(45.5 \%)$ \\
\hline $35 \mathrm{delG} / 312 \mathrm{del} 14$ & 20 & $(5.1 \%)$ \\
\hline 35delG / del(GJB6-D13S1830) & 3 & $(0.77 \%)$ \\
\hline 312 del14 / 312del14 & 2 & $(0.51 \%)$ \\
\hline $35 \mathrm{delG} / 235 \mathrm{delC}$ & 3 & $(0.77 \%)$ \\
\hline 167delT / 235delC & 2 & $(0.51 \%)$ \\
\hline $35 \mathrm{delG} / 182 \mathrm{M}$ & 2 & $(0.51 \%)$ \\
\hline 35delG / 167delT & 2 & $(0.51 \%)$ \\
\hline $35 \mathrm{delG} / \mathrm{V} 27 \mathrm{I}+E 114 G$ & 1 & $(0.26 \%)$ \\
\hline$N / 35 \mathrm{del} G$ & 14 & $(3.6 \%)$ \\
\hline$N / 312$ del14 & 4 & $(1.02 \%)$ \\
\hline N/167delT & 2 & $(0.51 \%)$ \\
\hline$N / V 27 I$ & 1 & $(0.26 \%)$ \\
\hline
\end{tabular}

* The mutations in exon 2 and del(GJB6-D13S1830) were detected by us previously [23].

people with normal hearing to establish the population rate of this recessive mutation. We were especially interested in establishing the genetic basis for NSHL in those patients with one or no mutation in the GJB2 second exon.

\section{Material and methods}

\section{Patient population}

Our patient group consisted of 391 children and teenagers (aged 2-18 years) with nonsyndromic hearing loss that came from the following towns located in different regions of Belarus: Minsk, Grodno, Pinsk, Bobruisk, Vitebsk, and Gomel. All underwent audiological analysis and the degree of their hearing loss was evaluated as moderate, profound, or severe. Written parental consent to conduct the study was provided.

\section{Control population}

Our control population was 300 ethnic Belarusians from six different regions of Belarus (North, East, West, Centre, South, and Eastern and Western Polessie); they were genotyped for the presence of the mutation IVS1+1G $>$ A in the non-coding part of the GJB2 gene. Different regions of the country were represented proportionally in both patient and control populations.

\section{Isolation of genomic DNA}

Genomic DNA was isolated from capillary blood and buccal epithelium using the standard protocol with Proteinase $\mathrm{K}$ and phenol-chloroform purification.

\section{Mutation IVS1+1A $>\mathrm{G}$ in the GJB2 gene}

All 391 patients and 300 controls were analysed for the presence of the mutation IVS1+1G $>A$ in the non-coding part of the GJB2 gene. To define the mutation IVS1+1G $>A$, PCR-RFLP analysis was carried out. Conditions for genotyping IVS1+1G $>$ A are presented in Table 2, where primers, annealing temperature, and endonuclease (Fermentas, Lithuania) are indicated. Visualisation of restriction fragments was performed in $7 \%$ polyacrylamide gel.

\section{Results}

We did not detect the IVS1+1G >A mutation in any of 300 samples from the control population with normal hearing, so we estimate that its carrier rate is less than $0.33 \%$. Similar results of population frequency have been obtained for two other European populations [13,22].

Following our previous study, all 391 patients that were genotyped for IVS1+1G $>$ A were divided into three groups: A: 28 patients with one mutant allele of GJB2 exon 2;

B: 150 patients that had neither mutations in the GJB2 coding exon nor deletion of GJB6 ( $\operatorname{del}(\mathrm{GJB} 6-\mathrm{D} 13 \mathrm{~S} 1830)$ );

C: 213 patients with two mutations detected in the second exon of GJB2 or with one mutation in that exon and a large deletion (del(GJB6-D13S1830)). Though the genetic basis of HL in group $\mathrm{C}$ was already determined [23], we checked them for IVS1 $+1 \mathrm{~A}>\mathrm{G}$ because there were some cases among our patients when people with NSHL carried three pathogenic mutations (unpublished).

There were 7 out of the 391 examined Belarusian patients $(1.8 \%)$ who carried the IVS1+1G $>$ A mutation. Out of these 7, 6 were heterozygous for the 35delG mutation (35delG/ IVS1+1G $>A$ ) and one was heterozygous for 312 del14 (Table 1), so all 7 patients belonged to group A. We did not find any patients with the IVS1+1G $>$ A mutation in the $\mathrm{B}$ or $\mathrm{C}$ groups.

Table 2. Primers, PCR conditions, and endonuclease for genotyping

\begin{tabular}{cccccc}
\hline Polymorphism & Primers & $\mathbf{T}_{\mathbf{a}}$ & $\begin{array}{c}\text { PCR product, } \\
\text { bp }\end{array}$ & Endo-nuclease & $\begin{array}{c}\text { Restriction fragments, bp } \\
\text { (allele type) }\end{array}$ \\
\hline $\mathrm{IVS} 1+1 \mathrm{~A}>\mathrm{G}$ & $\begin{array}{c}\text { F: ggtgtggggtgcggttaaaaggcg } \\
\text { R: cagtccggggccggcggggtca }[21]\end{array}$ & $60^{\circ} \mathrm{C}$ & $221 \mathrm{bp}$ & Eco911 & $\begin{array}{c}199,22(\mathrm{wt}) \\
221 \mathrm{bp}(\mathrm{mut})\end{array}$ \\
\hline
\end{tabular}


The degree of hearing loss varied among the identified carriers of the IVS1+1G $>$ A mutation. Severe HL was observed in 4 cases: 3 of them were compound heterozygotes IVS1+1G>A/35delG and the fourth had IVS1+1G $>A / 312$ del14 genotype. Profound HL was found in 2 patients, and both of them had IVS1+1 G>A / 35delG genotype. Only 1 patient (with IVS $1+1 \mathrm{G}>\mathrm{A} / 35 \mathrm{delG}$ genotype) had moderate HL. These data are in accordance with the results of Santos et al. (2005) and da Silva-Costa et al. (2009), who found that among patients with the $35 \mathrm{delG} / \mathrm{IVS} 1+1 \mathrm{G}>\mathrm{A}$ genotype, a severe or profound degree of HL predominates $[16,24]$.

Detection of a patient with moderate $\mathrm{HL}$ and genotype IVS $1+1 \mathrm{G}>\mathrm{A} / 35 \mathrm{delG}$ indicates that in rare cases the effect of IVS1+1G $>$ A mutation on HL is not particularly damaging [17].

\section{Discussion}

Mutations in the GJB2 gene play an important role in the etiology of hearing impairment. The major cause of pathological mutations has been identified in the second (coding) exon of this gene [22]. It is rare for mutations of the first non-coding exon and promoter region of the GJB2 gene to cause hearing loss, except for IVS1+1G>A. Only a few genetic laboratories include them in their standard protocols for HL screening [13,20,22,25].

The frequency of IVS1+1G>A mutation varies to a great extent among patients with HL from different ethnic groups. According to Tekin et al. (2010), IVS1+1G $>$ A is the most common pathogenic GJB2 allele among Mongolian patients with HL [10]. The highest carrier frequency of IVS1+1G $>A$ among six investigated Eastern Siberian populations had been found in the Yakut population [11]; surprisingly, mutation of IVS1+1G $>$ A accounts there for approximately $95 \%$ of all pathological mutations in the GJB2 gene [11]. Most of the identified Yakut patients were homozygotes $(\mathrm{IVS} 1+1 \mathrm{G}>\mathrm{A} / \mathrm{IVS} 1+1 \mathrm{G}>\mathrm{A})$, which is extremely rare in other ethnic groups studied up to now. According to these data, Eastern Siberia is the region with the most extensive accumulation of IVS1+1G $>$ A mutation in the world [11].

Among Western Europeans, the rate of IVS1+1G $>$ A mutation has not been thoroughly studied. In a group of 264 Dutch patients suffering from HL it was found to have very low frequency (2 out of 264) [21]. On the contrary, prevalence of IVS1+1G>A is typical for some patients from Eastern Europe - who are already carriers of one mutant GJB2 allele. Thus, among Czech and Hungarian patients with one pathogenic allele in the GJB2 coding exon, mutation of IVS $1+1 \mathrm{G}>\mathrm{A}$ accounts for $45 \%$ and $23.4 \%$ of cases, respectively. Our research detected a relatively high incidence of IVS1+1G $>$ A mutation: 7 cases out of 28 patients bore one pathogenic allele in the GJB2 coding exon (group A), which makes $25 \%$ for this cohort and is comparable with the rates published for the Czech and Hungarian patients $[13,22]$. Among Slovak patients the frequency of IVS $1+1 \mathrm{G}>\mathrm{A}$ mutation is about $1.85 \%$, which is significantly lower than in neighboring countries [19].

The question remains about the genetic basis of HL in the rest of the 21 patients who bear only one GJB2 mutation in exon 2 (last 4 rows in Table 1): 14 of them were $35 \mathrm{delG} / \mathrm{N}$ heterozygotes, 4 were $312 \mathrm{del} 14 / \mathrm{N}, 2$ were $167 \mathrm{delT} / \mathrm{N}$, and 1 patient was a V27I/N genotype. Various reasons of hearing loss in such patients have been discussed [26]:

- the second mutation exists in GJB2 but has not been detected (in the promoter or the first exon that were not sequenced);

- the cause of hearing impairment is a mutation in another, not "connexin" gene whose product reacts with connexin 26;

- several patients with a single mutation (recessive) are simply carriers, and their hearing impairment may result from other, nongenetic causes.

The background carrier rate of the $35 \mathrm{delG}$ mutation in Belarus has been previously determined in our study of 757 individuals with normal hearing to be $43 / 757=0.057$ (5.7\%), which is the highest rate in European countries published until now [23]. So we consider that the 14 patients who were $35 \mathrm{delG} / \mathrm{N}$ heterozygotes were probably mutation carriers whose hearing loss was caused other than by GJB2 mutation, as the rate, $14 / 391=0.036$, is even less than the 0.057 revealed for the general Belarus population. Concerning the 7 patients heterozygous for other pathogenic mutations (Table 1), further mutation search is needed to either confirm or exclude GJB2 involvement in hearing loss. For the rest of the 150 patients, mutations were not found either in the coding or non-coding parts of GJB2, so the genetic basis of their HL remains unproven.

In summary, we detected 7 cases of IVS1+1G $>$ A mutation in our group $\mathrm{A}$ and have not identified this mutation in groups $B$ or C. This result suggests that IVS $1+1 \mathrm{G}>\mathrm{A}$ is the third-most frequent mutation, after $35 \mathrm{delG}$ and $312 \mathrm{del} 14$, among Belarusian patients with $\mathrm{HL}$ - its rate is $1.8 \%$ for the whole cohort of 391 studied patients with HL.

\section{Conclusions}

The background carrier rate of IVS $1+1 \mathrm{G}>\mathrm{A}$ mutation in Belarus was determined to be less than $0.33 \%$.

Screening of IVS1+1G $>$ A mutation in a cohort of Belarusian patients with NSHL was conducted for the first time, and the rate of mutation carriers was estimated as $1.8 \%$.

Mutation of IVS1+1G>A in the non-coding part of the GJB2 gene is the third-most common pathogenic mutation, after 35delG and 312del14, in the spectrum of GJB2 mutations among Belarusian patients with NSHL.

According to our results, IVS1+1G $>\mathrm{A}$ is far more common in the compound heterozygous state, with other GJB2 mutations causing hearing impairment. Thus, it is probably not necessary to test all patients (in Eastern Europe) for this mutation; however, we recommend including tests for IVS1+1G $>$ A mutation in laboratory screening protocols for people with nonsyndromic hearing loss who are heterozygous for only one pathogenic exon 2 GJB2 mutation.

\section{Acknowledgements}

The authors would like to thank to Dr A. Kushnerevich, Dr L. Sivitskaja, and Docent T. Novogrodsky for their help in 
sample collection and V. Pankratov for valuable suggestions while discussing the results. We thank all the patients and Belarusian volunteers for their participation in the study.

\section{Conflicts of interest statement}

There are no conflicts of interest.

\section{Funding}

The work was supported by a project grant from the Belarusian Republican Foundation for Fundamental Research (BRFFR), project grant Б14P-081.

\section{References:}

1. Kokotas H, Laer L, Grigoriadou M, Iliadou V, Economides J et al. Strong linkage disequilibrium for the frequent GJB2 35delG mutation in the Greek population. Am J Med Genet, 2008; 146A: 2879-84.

2. Morton C, Nance W. Newborn hearing screening - a silent revolution. N Engl J Med, 2006; 354(20): 2151-64.

3. Pollak A, Skórka A. M34T and V37I mutations in GJB2 associated hearing impairment: evidence for pathogenicity and reduced penetrance. Am J Med Genet, 2007; 143A(21): 2534-43.

4. http://hereditaryhearingloss.org

5. Snoeckx R, Camp G. Non-syndromic hearing loss: cracking the cochlear code. Nature, 2007; 45: 227-39.

6. Wu C, Hung C, Lin S, Hsieh W, Tsao P et al. Newborn genetic screening for hearing impairment: a preliminary study at a tertiary center. PLoS ONE, 2012; 6(7): e22314.

7. Rodriguez-Paris J, Schrijver I. The digenic hypothesis unraveled: the GJB6 del(GJB6-D13S1830) mutation causes allele-specific loss of GJB2 expression in cis. Biochem Biophys Res Commun, 2009; 389(2): 354-9.

8. Lee J, White T. Connexin-26 mutations in deafness and skin disease. Expert Rev Mol Med, 2009; 11.e35.

9. Zhao H, Kikuchi T, Ngezahayo A, White T. Gap junctions and cochlear homeostasis. J Membrane Biol, 2006; 209(2-3): $177-86$

10. Tekin M, Xia X, Erdenetungalag R, Cengiz FB, White TW, et al. GJB2 mutations in Mongolia: complex alleles, low frequency, and reduced fitness of the deaf. Ann Hum Genet, 2010; 74(2): 155-64.

11. Barashkov N, Dzhemileva L, Fedorova S. Autosomal recessive deafness 1A (DFNB1A) in Yakut population isolate in Eastern Siberia: extensive accumulation of the splice site mutation IVS1+1G $>A$ in GJB2 gene as a result of founder effect. J Hum Genet, 2011; 56(9): 631-9.

12. Hutchin T, Coy N, Conlon H, Telford E. Assessment of the genetic causes of recessive childhood non-syndromic deafness in the UK: implications for genetic testing. Clin Genet, 2005; 68(6): 506-12.

13. Seeman P, Sakmaryova. High prevalence of the IVS $1+1 \mathrm{G}$ to A/ GJB2 mutation among Czech hearing impaired patients with monoallelic mutation in the coding region of GJB2. Clin Genet, 2006; 69(5): 410-13.

14. Denoyelle F, Marlin S, Marlin S, Weil D et al. Clinical features of the prevalent form of childhood deafness, DFNB1, due to a connexin-26 gene defect: implications for genetic counselling. Lancet, 1999; 353(9161): 1298-303.
15. Green G, Scott, McDonald J. Carrier rates in the midwestern United States for GJB2 mutations causing inherited deafness. JAMA, 1999; 281(23): 2211-16.

16. Mani R, Ganapathy A, Jalvi R. Functional consequences of novel connexin 26 mutations associated with hereditary hearing loss. Eur J Hum Genet, 2009; 17(4): 502-9.

17. Shahin H, Walsh T, Sobe T, Lynch E, King M et al. Genetics of congenital deafness in the Palestinian population: multiple connexin 26 alleles with shared origins in the Middle East. Hum Genet, 2002; 110(3): 284-89.

18. Bliznetz EA, Galkina AV, Matyushchenko GN, Kisina AG, Markova TG, et al. Changes in the connexin 26 gene (GJB2) in Russian patients with hearing loss: results of long-term molecular diagnostics of hereditary nonsyndromic hearing loss. Genetika, 2012; 48(1): 101-12.

19. Minárik G, Tretinárová D, Szemes T, Kádasi L. Prevalence of DFNB1 mutations in Slovak patients with non-syndromic hearing loss. Int J Pediatric Otorhinolaryngol, 2012; 76(3): 400-3.

20. Sansovic I, Knezevic J, Matijevic T, Balen S. Prevalence of the 35 delG mutation in the GJB2 gene of patients with nonsyndromic hearing loss from Croatia. Genet Test, 2005; 9(4): 297-300.

21. Santos RL, Aulchenko YS, Huygen PL, Donk KP, Wijs IJ. Hearing impairment in Dutch patients with connexin 26 (GJB2) and connexin 30 (GJB6) mutations. Int J Pediatric Otorhinolaryngol, 2005; 69(2): 165-74.

22. Tóth T, Kupka S, Haack B. Coincidence of mutations in different connexin genes in Hungarian patients. Int J Mol Med, 2007; 20(3): 315-21.

23. Danilenko N, Merkulava E, Siniauskaya M, Olejnik O. Spectrum of genetic changes in patients with non-syndromic hearing impairment and extremely high carrier frequency of 35delG GJB2 mutation in Belarus. PLoS ONE, 2012; 7(5): e36354.

24. da Silva-Costa SM, Coeli FB, Lincoln-de-Carvalho CR, Marques-de-Faria AP, Kurc M et al. Screening for the GJB2 c.-3170 G>A (IVS1+1G>A) mutation in Brazilian deaf individuals using multiplex ligation-dependent probe amplification. Genet Test, 2009; 13: 701-4.

25. Yuan Y, Yu F, Wang G, Huang S, Yu R et al. Prevalence of the GJB2 IVS1+1G >A mutation in Chinese hearing loss patients with monoallelic pathogenic mutation in the coding region of GJB2. J Transl Med, 2010; 8: 127. 